\title{
INWENTARZ RZYMSKOKATOLICKIEGO KOŚCIOLA PARAFIALNEGO W SIEHNIEWICZACH Z 14 MAJA 1930 ROKU
}

Pierwotny drewniany kościół parafialny w Siehniewiczach pw. Opieki Najświętszej Maryi Panny Różańcowej pochodził z połowy XVI wieku. Parafia od początku należała do diecezji łucko-brzeskiej. Fundatorami kościoła byli Florian i Anna Radogowscy. W czasach staropolskich parafia posiadała patronat szlachecki i należała do dekanatu Szereszów ${ }^{1}$. W 1785 roku murowaną świątynię barokową w Siehniewiczach ufundowali Józef i Maria Prozorowie ${ }^{2}$. Została ona odnowiona w 1848 roku. W 1915 roku świątynia została spalona przez armię rosyjską. Dopiero w II Rzeczypospolitej - w 1922 roku została wybudowana świątynia dzięki wsparciu Neuhoffa von Leya, dobrodziejów i staraniem ówczesnego pro-

* Ks. Waldemar Witold Żurek SDB - dr hab. historii Kościoła; adiunkt w Ośrodku Archiwów Bibliotek i Muzeów Kościelnych KUL; e-mail: zurek@kul.pl

ORCID 0000-0002-5602-5077

${ }^{1}$ S. Litak, Kościót łacińscy w Rzeczypospolitej około 1772 roku, Lublin 1996, s. 386.

${ }^{2}$ Prozor Józef herbu własnego (1723-1788) - wojski kowieński w 1755 roku, poseł na sejm kowieński w 1756 i 1758 roku, obersztelejtnant Jego Królewskiej Mości w 1756 roku, od 1762 roku generał-major armii Wielkiego Księstwa Litewskiego, w 1764 roku starosta kowieński, poseł na sejm konwokacyjny w 1764 roku z powiatu kowieńskiego, kasztelan witebski 1774-1781, w 1776 roku członek Rady Nieustającej, marszałek Trybunału Głównego Wielkiego Księstwa Litewskiego w 1781 roku, wojewoda witebski 1781-1787. Kształcił się w Akademii Rycerskiej w Lunéville do 1741 roku. Otrzymał patent na porucznika piechoty Księstw Lotaryngii i Baru. Był członkiem konfederacji generalnej Wielkiego Księstwa Litewskiego w 1764 roku, członkiem Departamentu Skarbowego Rady Nieustającej w 1777 roku. Na Sejmie rozbiorowym w 1775 roku powołany został do Komisji Skarbowej Wielkiego Księstwa Litewskiego. Odznaczony został Orderem Orła Białego w 1785 roku i Orderem Świętego Stanisława w 1775 roku. Poślubił Felicjannę Niemirowicz-Szczytt (po 1764), z którą miał synów: Karola, Antoniego, Ignacego Kajetana oraz córki: Petronelę i Mariannę. Po przedwczesnej śmierci Felicjanny (†1766), ożenił się ponownie w 1767 z Aleksandrą Zaranek (†1771), z którą miał dwie córki: Różę i Barbarę. Trzecią żoną była Marianna Chalecka vel Adamowa Szujska (1751-1826), z którą nie miał potomstwa. Z. Zielińska, Józef Prozor, w: Polski Stownik Biograficzny, t. 28, Wrocław 1984-1985, s. 532. 
boszcza (do połowy lipca 1930 roku) ks. Izydora Niedroszlańskiego³. Po drugiej wojnie światowej Siehniewicze znalazły się w granicach Związku Sowieckiego (Ukraińskiej Socjalistycznej Republice Radzieckiej). W 1949 roku kościół parafialny został zamknięty przez komunistyczne władze. Dzięki staraniom wiernych i duchowieństwa w 1989 roku świątynia została zwrócona wiernym i odremontowana ${ }^{4}$.

Obecnie Siechniewicze położone są w obwodzie (województwie) brzeskim, rejonie (powiecie) Bereza, w niepodległej od 1991 roku Ukrainie.

Sporządzony w maju 1930 roku inwentarz kościoła parafialnego w Siehniewiczach przez ustępującego proboszcza ks. Izydora Niedroszlańskiego ${ }^{5}$ dla swego następcy ks. Henryka Kazimierowicza ${ }^{6}$, ostatecznie została przejęta przez ks. Bolesława Leszczyńskiego, który w tej parafii został proboszczem.

${ }_{3}^{3}$ Spis kościołów i duchowieństwa diecezji pińskiej w R. P. 1939, Pińsk 1939, s. 130.

${ }^{4}$ G. Rąkowski, Ilustrowany przewodnik po zabytkach kultury na Biatorusi, Warszawa 1997, s. $212-213$.

${ }^{5}$ Ks. Niedroszlański Izydor (1887-1950) - kapłan diecezji pińskiej. Święcenia kapłańskie przyjął w 1911 roku. Był proboszczem w Siehniewiczach od 1921 do połowy lipca 1930 roku. Następnie pełnił obowiązki proboszcza w parafii św. Andrzeja Apostoła w Wyszkach, dekanat Bielsk Podlaski, rejon Brańsk, gdzie pracował do 1948 roku. To w tej miejscowości na polecenia ks. Nidroszłańskiego naprzeciwko trybuny ustawiono krzyż, udekorowany kwiatami i zielenią. Działanie to zostało zaliczone przez władze do wystąpień antyradzieckich i działań „kontrrewolucyjnych”. Elenchus ecclesiarum et cleri dioecessis pinsceensis pro Anno Domini 1928, Pinsci 1928, s. 97; Mikhailik, Kościót katolicki na Grodzieńszczyźnie 1939-1956, Warszawa 2008, s. 102; Z. Rostkowski, Historia parafii pw. św. Andrzeja Apostoła w Wyszkach, „Niedziela”, http://niedziela.pl/wydruk/28896/nd (dostęp: 20.11.2018).

${ }^{6}$ Kazimierowicz Henryk (1896-1942) - kapłan diecezji włocławskiej. Studia seminaryjne rozpoczął we włocławskim seminarium duchownym, w którym dnia 22 czerwca 1919 roku przyjął święcenia kapłańskie. Był wybitnie uzdolnionym człowiekiem. Jako neoprezbiter objął obowiązki katechety gimnazjum w Praszce. W roku następnym podjął studia humanistyczne na KUL. Z powodów charakterologicznych miał na uniwersytecie trudności. Dwa lata później przeniósł się na Uniwersytet Warszawski. W 1923 roku wyjechał na studia do Rzymu, skąd powrócił ze stopniem doktora filozofii i teologii. Po powrocie, w ciągu 1923 roku pracował w gimnazjum w Łowiczu i wypełniał obowiązki wikariusza parafii $\mathrm{w}$ tym mieście. W jesieni tego roku został powołany na wykładowcę historii filozofii i kryteriologii na UW. Po dwóch latach pracy w diecezji łódzkiej, gdzie pracował za zezwoleniem ordynariusza włocławskiego, przeniósł się do Włocławka. Pragnął dalej studiować. W 1926 roku przeniósł się do diecezji pińskiej. Tam pracował jako wykładowca w seminarium duchownym w Pińsku oraz podjął pracę duszpasterską w parafii Łachwa. Stąd miał w 1930 roku przejść na parafię Siehniewicze. Niestety do tego nie doszło. W tym roku objął parafię Stolin. Następnie pracował w Mielniku nad Bugiem. W tym czasie ogłosił szereg mniejszych prac z historii Kościoła, religiologii, psychoanalizy. W 1936 roku był nauczycielem w gimnazjum w Brześciu Litewskim. Do diecezji włocławskiej powrócił w październiku 1936 roku. Podjął pracę w parafii Bronisław. Ponieważ był człowiekiem bardzo aktywnym poprosił o inną placówkę. W sierpniu 1937 roku został przeniesiony do Tołkini. Dnia 6 października 1941 roku został aresztowany przez Niemców w Tołkini i skierowany do miejsca zbiorowego aresztu w Konstantynowie Łódzkim, skąd przewieziono go do niemieckiego obozu koncentracyjnego w Dachau. Wyczerpany ciężkimi warunkami obozowymi i nadludzką pracą, zapisano go na listę inwalidów. Zaliczony na śmierć przez zagazowanie, w sierpniu 1942 roku zakończył życie. Elenchus ecclesiarum et cleri dioecessis 
Opis fizyczny dokumentu: Inwentarz Siehniewickiego rzymskokatolickiego kościoła ... z dnia 14 maja 1930 roku.

Dokument składa się z trzech luźnych kart o wym. 446×350 mm złożonych wzdłuż na pół, tworząc sześć kart $(223 \times 350 \mathrm{~mm})$ tj. 12 stron. Na papierze wyprodukowanym maszynowo o lekko kremowej barwie, na stronach: 1, 3-6 i w trzech linijkach na stronie 7, tekst wypisany został maszyną do pisania. Pierwsza strona zawiera tytuł: Inwentarz Siechnickiego rz-kat. Parafialnego kościoła sporzadzony przez ks. Izydora Niedroszlańskiego przy zdaniu niniejszego nowo mianowanemu proboszczowi ks. Henrykowi Kazimierowiczowi w myśl zarzadzenia J. E. Ks. Biskupa Pińskiego z dnia 14 maja 1930 roku pod Nr 1096/30. Na stronach 5 i 6 znajduje się tabela o czterech kolumnach, wyrysowana niebieską kredką. Tekst kończy się na 7 stronie ręcznym dopiskiem. Na wszystkich zapisanych stronach, widoczne są odręczne wpisy naniesione czarnym atramentem. Strony: 2 i 8-12 nie są zapisane. W dolnej części przedniej karty, w miejscu złożenia dokumentu, doklejona jest mała karteczka, na której pismem maszynowym umieszczona jest informacja o treści dokumentu i data.

Stan zachowania - listopad 2016 roku. Dokument poddany został zabiegom konserwatorskim. Ubytki uzupełniono papierem odpowiadającym gramaturze dokumentu, przedarte brzegi i złożenie kart wzmocniono bibułką japońską. Karty zostały przyklejone klejem.

Dokument zabezpieczony jest tekturową teczką.

\section{Tekst dokumentu}

INWENTARZ Siehniewickiego rz.-kat. parafialnego kościoła sporzadzony przez ks. Izydora Niedroszlańskiego przy zdaniu niniejszego nowo mianowanemu proboszczowi ks. Henrykowi Kazimierowiczowi. w myśl zarzadzenia J. E. Ks. Biskupa Pińskiego z dnia 14 maja 1930 roku pod Nr 1096/307

\section{[s. 3] Historja Siehniewickiego Rzym[sko]-kat[olickiego] parafialnego ko- ścioła}

Siechniwicki rz[ymsko]-kat[olicki] paraf[ialny] kościół należy obecnie do diecezji pińskiej, wojew[ództwa] poleskiego, starostwa i dekanatu próżańskiego niegdyś należał do diecezji Łucko-Brzeskiej. Niewiadomo kiedy i przez kogo był wybudowany drewniany kościół w Siehniewiczach, jednak można przypuszczać, że pochodził on z XVII wieku jak widać z ksiąg metrykalnych znajdujących się w archiwum kościelnym a mianowicie: księgi ślubne z 1657 r. i księgi chrzestne z $1676 \mathrm{r}$.

pinscensis pro Anno Domini 1928-32, Pinsci 1928-32; Kazimierowicz Henryk, w: S. Librowski, Ofiary zbrodni niemieckich spośród duchowieństwa diecezji włocławskiej 1939-1945, Włocławek 1947, s. 61-62.

${ }^{7}$ Oryginał znajduje się w ADD, Zespół: Archiwum Parafii Siehniewicze, sygn. III/J/2 (Od Ks. Kazimierza Świątka). 
Obecny kościół w Siehniewiczach murowany został wybudowany w 1785 roku przez Józefa i Marię z hrabiów Galickich Prozorów, wojewod[ów] Litewskich pod wezwaniem Opieki Matki Boskiej (Patrocinii B.M.V.) jak widać z bulli Papieża Piusa VI wydanej 26 listopada 1786 roku wyżej wymienionemu Józefowi Prozorowi.

Rozmiar kościoła siehniewickiego $28 \times 10$ m. przy kościele przybudowane są dwie kaplice.

Kościół zwrócony głównym wejściem do zachodu, facjata ${ }^{8}$ kościoła w prostej linii, przy której znajdują się dwie wieże kwadratowe, a trzecia mała okrągła nad wielkim ołtarzem. Wierzchnia część wież zrobiona z desek i pokryte są blachą, na wieżach żelazne krzyże. Przy wieżach znajdują się dwie rynny drewniane pokryte blachą.

W 1899 roku kosztem p. [Anny] Mikulskiej cały kościół był odnowiony, jak również na wieżach i zakrystiach gonty dano nowe. $Z$ frontu kościoła 2 duże okna, bocznych okien 6, z których przy wielkim ołtarzu 2, w 1899 roku kosztem p. [Anny] Mikulskiej zrobiono żelazne ramy i oszklone różno kolorowym szkłem. W kaplicach również po dwa małe okna, o żelaznych ramach (witraże). W zakrystiach 2 weneckie okna z kratą żelazną wychodzą na zewnątrz kościoła i 2 do części ołtarzowej. W lewej wieży dwa okna i nad zakrystiami w szczytach od wielkiego ołtarza 2 małe okna. Ogólna liczba okien 19. Wszystkich drzwi w kościele 11.

Sufit w kościele, zakrystiach, kaplicach i wieżach drewniany malowany w 1899 roku. Posadzka w całym kościele z tafli cementowych, a w prezbiterium i zakrystiach ze sztucznego marmuru.

Archiwum kościelne znajduje się w lewej wieży. W prawej wieży umieszczone są dzwony. Organ nowy o dziesięciu głosach, zbudowany w 1900 r. kosztem p. [Anny] Mikulskiej przez firmę Jana Szymańskiego ${ }^{9}$ w Warszawie.

[s. 4] Utrzymanie. Siehniewicki kościół zaliczony do IV klasy ${ }^{10}$ i otrzymuje od Rządu 275 rb[rubli] na utrzymanie kościoła i służby kościelnej.

${ }^{8}$ Facjata (mansard) - mieszkalne pomieszczenie znajdujące się w kondygnacji strychowej, wydzielone z niej ścianami, najczęściej nadbudowane i posiadające odrębne zadaszenie.

${ }^{9}$ Szymański Jan (1828-1892) - polski organmistrz. Urodził się w Kościerzynie koło Łowicza. Był synem Andrzeja, organisty. Od 1861 roku prowadził firmę organmistrzowską w Częstochowie, a od 1868 roku zamieszkał w Warszawie na ul. Chłodnej, gdzie prowadził swoją firmę do 1880 roku pod nazwą: Józef Szymański i Syn. Za jego życia i w jego firmie zbudowano 126 instrument ow. Był jednym z kilku polskich organmistrzów (J. Śliwiński - w Kętach 1880 roku. A. Hofman - w Chmielniku 1891 roku. L. Blomberg - w Lublinie 1893), którzy przy budowie organów w kościołach polskich zastosowali wiatrownice stożkowe i wolno stojące kontaury przed szafą organową. Szymański zastosował je przy budowie organów w kościele św. Jana Chrzciciela na Bródnie w Warszawie. Zmarł w Warszawie. Józef Szymański, w: Encyklopedia muzyczna PWM, Sm-Ś. Część Biograficzna, red. E. Dziębowska, Kraków 2007, s. 298.

${ }^{10}$ Ukazy carskie z 1 stycznia oraz z 15 grudnia 1843 roku podzieliły biskupstwa katolickie w Cesarstwie Rosyjskim na klasy, od których uzależniano wysokość uposażenia diecezji, biskupa, parafii i niższego duchowieństwa diecezjalnego. Parafie podzielone zostały na pięć klas, na podstawie których proboszczom parafii z poszczególnych klas wyznaczono pensję etatową w wysokości od 235 do 600 rubli rocznie. Większość parafii należała do klasy V. B. Kumor, Ustrój i organizacja 
W roku 1915 kościół siehniewicki z wszystkimi budynkami został spalony przez wojska rosyjskie, pozostały tylko mury, a w roku 1925 został odbudowany. Zdjęto $1 \mathrm{~m} .50 \mathrm{~cm}$. starego zepsutego muru na całym kościele i wieżach kościelnych, a dano nowy. Ułożono nowe belki, zaciągnięto nowe krokwie i sporządzono wiązanie dachowe oraz pokryto cały kościół nowymi gontami, wieże zaś - na których umieszczono żelazne krzyże, pokryto blachą ocynkowaną. Przy wieżach od kościoła umieszczono dwie rynny drewniane wyłożone blachą ocynkowaną. Gzymsy są częściowo pokryte nową blachą ocynkowaną częściowo zaś żelazną. Cały kościół wewnątrz i zewnątrz otynkowany i wybielony wapnem. Wszystkich drzwi w kościele 10. Wielkie drzwi głównego wejścia podwójne, umocowane na żelaznych zawiasach, bez zamku, zamykają się tylko na haki. Od głównego wejścia w lewej wieży umieszczono schody, które prowadzą na chór. Na chórze jedne drzwi pojedyncze umocowane na żelaznych zawiasach bez zamku, tylko zamykają się na haczyk od wewnątrz chóru. Drugie drzwi na chórze, które prowadzą do prawej wieża gdzie było archiwum drzwi nie ma, tylko futryna wmurowana i zabite deskami. Na chórze umieszczona fisharmonia firmy Hofberg - I. Grosspiet$\operatorname{sch}^{11}$ o 7 registrach. Przy wejściu z babińca są wmurowane 3 futryny lecz bez drzwi. Dwoje bocznych mniejszych i jedna duża vis a'vis gł[ównego] wejścia. W lewej zakrystii dwoje drzwi pojedynczych na zawiasach i z wewnętrznymi zamkami. W prawej zakrystii wchodząc $<$ do $>$ kościoła drzwi nie ma, tylko murowana futryna. Wychodząc na cmentarz kościelny z zakrystii są drzwi pojedyncze na zawiasach i z wewnętrznym zamkiem.

Ogólna liczna okien w kościele 17. Jedno okno w szczycie z frontu kościoła, 1 okno na chórze, 1 okno w prawej wieży, gdzie było archiwum, dwa okna w lewej wieży gdzie były dzwony, lecz bez futryn, zabite deskami. 2 okna weneckie w dużym kościele, po 2 okna małe o żelaznych ramach w kaplicach, 1 okno weneckie w prawej i $1 \mathrm{w}$ lewej zakrystii; 2 okna w szczytach ponad zakrystiami i 2 duże okna w prezbiterium. Wszystkie okna są oszklone. W całym kościele nowy sufit, lecz nie malowany, ambona zwykłej stolarskiej roboty. Posadzka w całym kościele poprawiona.

\section{Beneficjum kościelne}

Siehniewicki rzymsko-kat[olicki] parafialny kościół posiada na danej ziemi w 1842 roku (33 dziesięciny) 37 ha $2422 \mathrm{~m}^{2}$, z których według planu przypada pod ogrody, place i zabudow[ania] 1 ha $9352 \mathrm{~m}^{2}$. Grunta orne 19 ha $8932 \mathrm{~m}^{2}$, tąki 7 ha $0226 \mathrm{~m}^{2}$, pastwiska 3 ha $7087 \mathrm{~m}^{2}$, cmentarz kościelny $2607 \mathrm{~m}^{2}$, zarośla 1 ha

Kościoła polskiego w okresie niewoli narodowej 1772-1918, Kraków 1980, s. 306; S. Litak, Kościót taciński w Rzeczypospolitej około 1772 roku, Lublin 1996, s. 78-79.

${ }^{11} \mathrm{~W}$ niemieckim Wrocławiu (Breslau), przemysł fortepianowy był bardzo rozwinięty. Pierwszego znanego mistrza produkującego instrumenty klawiszowe - G. Baumgartena notowano w roku 1635. Manufakturą produkującą fortepiany na skalę przemysłową we Wrocławiu była firma „Traugott Berndt” i najdłużej działająca w tym mieście - w latach 1837-1945. Jan Grosspietsch (zm. w 1901) od 1848 roku (lub od 1866) produkował we Wrocławiu własne pianina i instrumenty muzyczne, a po jego śmierci firmę prowadziła rodzina. Produkcja fortepianów w przedwojennym Wrocławiu, http://arspolonica.ocross.net/produkcja-fortepianow-we-wroclawiu/ (dostęp: 20.11.2018). 
$3258 \mathrm{~m}^{2}$, łąka [s. 5] mokradła 1 ha $5033 \mathrm{~m}^{2}$, stawy $2055 \mathrm{~m}^{2}$, rowy $1829 \mathrm{~m}^{2}$, drogi 1 ha $2043 \mathrm{~m}^{2}$.

\section{Zabudowania gospodarcze}

1. Dom mieszkalny rozmiar $15 \times 6 \mathrm{mtr}$ [=metrów] składający się z 4 -ch pokoi, przedpokoju, kuchni, pokoju dla służby, spiżarni i sionki.

2. Obora, stajnia i wozownia pod jednym dachem rozmiar $18 \times 8 \mathrm{mtr}[=$ metrów]

3. Stodoła na zboże o dwóch drzwiach rozmiar $20 \times 9 \mathrm{mtr}$ [metrów]

4. Chlew dla chlewni zbudowany z opołów ${ }^{12}$ rozmiar $6 \times 4$ mtr[metrów]

Do parafii siehniewickiej należą gminy: Rewiatycze, Międzylesie i część gm[iny] Marywil.

\section{Inwentarz kościelny}

\begin{tabular}{|c|c|c|c|}
\hline Pozostało po spalonym kościele: & & Patena pozłacana do chorych & 1 \\
\hline Monstrancja & 1 & Krzyż drewniany z fig[urą] P[ana] Jezusa & 2 \\
\hline Dzwon przy kościele & 1 & $\begin{array}{l}\text { Naczynie do wody chrzest[nej] emali[owa- } \\
\text { ne] }\end{array}$ & 1 \\
\hline Dzwonek przy zakrystii & 1 & Baldachim $^{\mathrm{a}} \mathrm{z}$ serw[ety] o 4-ch drążkach & 1 \\
\hline Dzwonek mały & 1 & Konfesjonałów prowizorycznych & 2 \\
\hline Lichtarz żelazny pod paschał & 1 & Obraz M[atki] B[oskiej] Częstochowskiej & 1 \\
\hline $\begin{array}{l}\text { Żelazo do wyp[iekania] opłatków } \\
\text { (stare) }\end{array}$ & 1 & Obraz M[atki] B]ożej] Bolesnej & 1 \\
\hline Tabernakulum & 1 & $\begin{array}{l}\text { Obraz Naj[świętszego] Serca P[ana] } \\
\text { Jezusa }\end{array}$ & 1 \\
\hline $\begin{array}{l}\text { Figury żelazne: M[atki] Bożej, } \\
\text { św. Heleny, św. Michała Archanioła } \\
\text { razem }\end{array}$ & 3 & $\begin{array}{l}\text { Obraz mały M[atki] B[ożej] N[nieustają- } \\
\text { cej] Pomocy }\end{array}$ & 1 \\
\hline Nabyto do kościoła: & & $\begin{array}{l}\text { Obraz mały M[tki] B[oskiej] Ostrobram- } \\
\text { skiej }\end{array}$ & 1 \\
\hline Kielich mały, srebrny złocony & 1 & $\begin{array}{l}\text { Chorągiew niebieska } \mathrm{z} \text { monogr[amem] } \\
\mathrm{M} \text { [atki] } \mathrm{B} \text { [ożej] }\end{array}$ & 1 \\
\hline $\begin{array}{l}\text { Puszek plater[owanych }]^{\mathrm{b}} \text { do Sanctis- } \\
\text { simum }\end{array}$ & 2 & Komody & 2 \\
\hline Krzyżyk mosiężny złocony & 1 & Krzesło & 1 \\
\hline Lichtarze wernikowe małe & 2 & Dywany samodziałowe & 3 \\
\hline Puszka aluminjowa do hostji & 1 & Dywan. wełnianych grubych & 2 \\
\hline
\end{tabular}

${ }^{a}$ Baldachim - osłona z ozdobnej tkaniny, umocowana na dwóch lub czterech drążkach. Pierwotnie noszona nad władcami i dostojnikami. Później i obecnie podczas uroczystości kościelnych, głównie procesji, nad przedmiotami kultu: relikwiami i Najświętszym Sakramencie.

${ }^{b}$ Platerować (niem. plattierum) - pokrywanie metalu mniej szlachetnego warstwą metalu szlachetniejszego, np. miedź folią srebrną lub złotą, w celu ozdobienia lub zabezpieczenia przed korozją.

${ }^{12}$ Opoły - to zrzyny tartaczne drzewa, boki, resztki, jako produkt opałowy. Zrzyny tartaczne/ opoły to odpady iglaste: sosnowe i świerkowe oraz odpady liściaste: głównie brzozowe i olchowe. Półokrągłe opoły - deski z naturalną krzywizną krawędzi, dają bardzo plastyczny obraz płotu. 


\begin{tabular}{|l|c|l|c|}
\hline $\begin{array}{l}\text { Naczynia z tacką plater[owaną] } \\
<\text { do> Ol[ejów] św[iętych] }\end{array}$ & 1 & Klęcznik mah[oniowy] & 1 \\
\hline Dzwonek mały & 1 & Lichtarze miedziane małe & 2 \\
\hline Ampułki szklane & 2 & Skarbonka blaszana & 1 \\
\hline $\begin{array}{l}\text { Lampka wisząca przed Sanctissi- } \\
\text { mum }\end{array}$ & 1 & Miseczka do wody & 1 \\
\hline Tabernakulum jesionowe & 1 & Kanony na ołtarz komplet razem & 3 \\
\hline $\begin{array}{l}\text { Figura drewniana duża P[ana] } \\
\text { Jezusa }\end{array}$ & 1 & Całun żałobny & 1 \\
\hline Figura gips św. Antoniego & 1 & Pieczęć kościelna z poduszką & 1 \\
\hline $\begin{array}{l}\text { Tron z jedwabiu do wystawienia } \\
\text { Najświętszego Sakramentu }\end{array}$ & 1 & Waskulum ${ }^{a}$ szklane & 1 \\
\hline Żyrandol mosiężny o 12 świec & 1 & Wycinacz do komunikantów & 1 \\
\hline Mszał żałobny & 1 & Portatyl nowy w ołtarzu z 1922 r. & 1 \\
\hline Ewangeliczka & 1 & Poduszki pod mszał & 2 \\
\hline
\end{tabular}

[s. 6]

\begin{tabular}{|l|c|l|c|}
\hline Ołtarzyk stary do procesji & 1 & Obrusów na ołtarz & 3 \\
\hline $\begin{array}{l}\text { Puszka pozłacana pęk[nięta] } \\
\text { z krzyżem ułamanym }\end{array}$ & 1 & Ręczników & 3 \\
\hline $\begin{array}{l}\text { Patena pozłacana na podstawie zła- } \\
\text { manej }\end{array}$ & 1 & Płótna & 7 \\
\hline Figura Zmartwychwstania & 1 & Korporałów $^{c}$ & 10 \\
\hline Paschał & 1 & Palek $^{\mathrm{d}}$ & 4 \\
\hline
\end{tabular}

${ }^{a}$ Vasculum, waskulum, wasculum (łac. małe naczynko) - naczynie liturgiczne z wodą, głównie stojące przy tabernakulum. Służy do obmywania (ablucji) palców przez szafarza po udzieleniu komunii świętej, bądź umieszczenia w nim drobnych partykuł Najświętszych Postaci, bądź upadłej Hostii Świętej, która rozpuszcza się w znajdującej się w nim wodzie.

${ }^{\mathrm{b}}$ Portatyl - niewielkich rozmiarów ołtarz przenośny, do sprawowania Eucharystii poza kościołem. Portatyle zapoczątkowane zostały w liturgii już w III wieku, w związku z celebracją Eucharystii w więzieniach. Od połowy IV wieku umieszczano w ołtarzach i w portatylach relikwie świętych. Sprawowanie Eucharystii poza kościołem bez portatylu było zabronione. Reforma liturgiczna po Soborze Watykańskim II zniosła obowiązek stosowania portatyli. K. Cichoń, M. Konieczny, Portatyl, w: Encyklopedia katolicka (dalej: EK), t. 16, Lublin 2012, kol. 7-8.

${ }^{c}$ Korporał - parament liturgiczny w kształcie kwadratowego obrusu o boku ok. $50 \mathrm{~cm}$, na którym umieszcza się Postacie eucharystyczne w czasie Mszy Świętej i w ramach kultu Eucharystii poza Mszą Świętą. Na korporale umieszcza się patenę z chlebem - Ciałem Pańskim i kielich w winem - Krwią Pańską podczas Mszy Świętej, kustodię oraz puszkę lub monstancję podczas wystawienia Najświętszego Sakramentu. Służy też do obrzędu udzielania komunii poza Mszą Świętą oraz do wyłożenia tabernakulum. M. Straszewicz, Korporał, EK, t. 9, Lublin 2002, kol. 900-901.

${ }^{\text {d }}$ Palka - kwadratowy, usztywniony kawałek płótna, służący do nakrywania kielicha mszalnego w celu uchronienia Najświętszej Krwi przed zabrudzeniem. 


\begin{tabular}{|c|c|c|c|}
\hline Kndelabrya, ofiara p. Hendlera & 2 & Puryfikaterzy $^{\mathrm{b}}$ & 14 \\
\hline Katafalk $^{\mathrm{c}}$ o 5-ciu stopniach & 1 & Księgi metryczne: & \\
\hline Stół drewniany duży & 1 & Chrzestne od 1916-1921 roku & \\
\hline Ornaty: & & Chrzestne od 1921-1925 roku & \\
\hline $\begin{array}{l}\text { Biały z Słuck. pas. ofiara pani Sze- } \\
\text { miothowej }\end{array}$ & 1 & Chrzestne od 1926 w użyciu & \\
\hline $\begin{array}{l}\text { Biały zw[yczajny] } 1 \text { o b biało-sbre- } \\
\text { br[nych] bok[ach];1 o[nnat] żółto- } \\
\text { sreb[rny] }\end{array}$ & 2 & Ślubne od 1917 w użyciu & \\
\hline$<$ Ornat $>$ żółty & 1 & Pogrzebowe od 1916 w użyciu & \\
\hline Kapa fioletowa & 1 & Egzaminów przedślubnych & \\
\hline Alby & 2 & Księga konwertytów od 1917 r. & \\
\hline Pasów do alb & 2 & Spis parafialny & \\
\hline Komże duże & 2 & Kronika parafii siehniewickiej & \\
\hline Komże małe & 5 & Księga zapowiedzi od 1921 roku & \\
\hline Stuła fioletowa $\mathrm{z}$ drugiej strony biała & 1 & Dokumenta od 1923 do 1929 roku & \\
\hline Stuła czerwona & 1 & & \\
\hline
\end{tabular}

Dokumenta pozostawione przez ks. Chodkowskiego.

Plan beneficjum sporządzony $1928 \mathrm{r}$.

Wzięto z kościoła kobryńskiego od ks. dziekana Rossołowskiego, do kościoła siehniewickiego w 1916 roku stare paramenta kościelne:

${ }^{a}$ Kandelabr - znacznych rozmiarów, stojący, kilkuramienny świecznik wykonany był głównie z metalu. Popularne w XVII wieku kandelabry dwuramienne, już w XVIII wieku były trójramienne, w następnych stuleciach nawet kilkunastoramienne. Ze względu na swe rozmiary kandelabr zbudowany był z podstawy, trzonu i najczęściej zdejmowanej nastawy z ramionami. D. Forstner, Świat Symboliki Chrześcijańskiej, Warszawa 1990, s. 410.

${ }^{b}$ Puryfikaterz - biały, płócienny ręczniczek służący do wycierania kielicha w czasie Mszy Świętej i opróżnionej puszki z tabernakulum, w czasie puryfikacji, czyli oczyszczania naczyń liturgicznych (kielich, patena, puszka) używanych do sprawowania lub przechowywania Eucharystii. Po Soborze Watykańskim II puryfikacji dokonuje kapłan, diakon lub akolita na boku ołtarza lub kredensie. A. Pleskaczewska, Puryfikacja, EK, t. 16, Lublin 2012, kol. 630-631.

${ }^{\mathrm{c}}$ Katafalk - to podwyższenie, na którym w kaplicy pogrzebowej lub kościele stawia się trumnę w czasie obrzędu ostatniego pożegnania lub Mszy Świętej pogrzebowej. W przeszłości znane były trzy rodzaje katafalków: 1/ Feretron (mary), używany podczas procesji jako nosze do relikwii, figury lub obrazu, 2/ Katafalk mniejszy, czyli stołeczki lub stopnie (gradusy) pod trumnę, 3/ Katafalk większy, składający się z trzech lub więcej stopni. Katafalk używano podczas skromniejszych pogrzebów, gdy nie wznoszono castrum doloris (rozpięty nad katafalkiem baldachim w czasie uroczystego, kilkudniowego pogrzebu) - stosowany w kulturze chrześcijańskiej od średniowiecza, a w XVII i XVIII wieku osiągnął bogactwo form. Posoborowa reforma liturgii ograniczyła i ujednoliciła przepisy na temat stosowania katafalku, który należy stawiać na środku kościoła, tak by trumna nie zasłaniała ołtarza. Na trumny osoby świeckiej można położyć Pismo Św. W niektórych regionach stawia się świeczki, krzyż, różaniec. Na trumnie diakona lub kapłana stawia się kielich oraz kładzie mszał. Na trumnie biskupa mitrę. T. Syczewski, Katafalk, EK, t. 8, Lublin 2000, kol. 976. 
Ornaty:

1 biały, 1 zielony, 1 fioletowy, 1 czerwony i 1 czarny razem - 5

Kapy:

1 biała, 1 zielona, 1 czerwona i 1 czarna razem - 4

Stuły:

1 fioletowa, 1 zielona i 1 czarna razem - 3

1 welon na puszkę, 1 obrus na ołtarz

2 komże, 2 alby, 2 humerały, 1 pasek do alby, 1 ręcznik, 2 ręczniczki, 3 korporały, 6 puryfikaterzy, 3 palek, 1 dywan fabryczny, 1 krzyż procesyjny metalowy, lichtarze małe jednakowe 4.

1 kociołek do wody, 1 łódka z łyżeczką do kadzielnicy, 1 kadzielnica, tacki małe metalowe 2, ampułka metalowa do chrztu 1 .

[s. 7] Kościół i beneficjum kościelne zgodnie z powyższym inwentarzem zdałem księdzu Bolesławowi Leszczyńskiemu ${ }^{13}$.

Dnia[14 maja] 1930 roku.

ks. I[zydor] Niedroszlański ${ }^{14}$

Kościół i beneficjum kościelne zgodnie z powyższym inwentarzem przyjąłem dnia 15 lipca 1930 roku.

ks. Bolesław Leszczyński

\section{BIBLIOGRAFIA}

Cichoń Krysztof, Konieczny Mariusz, Portatyl, w: Encyklopedia Katolicka, t. 16, Lublin 2012, kol. 7-8.

Elenchus ecclesiarum et cleri dioecessis pinsceensis pro Anno Domini 1928, Pinsci 1928. Elenchus ecclesiarum et cleri dioecessis pinsceensis pro Anno Domini 1932, Pinsci 1932. Forstner Dorothea, Świat Symboliki Chrześcijańskiej, Warszawa 1990.

Kazimierowicz Henryk, w: S. Librowski, Ofiary zbrodni niemieckich spośród duchowieństwa diecezji włocławskiej 1939-1945, Włocławek 1947, s. 61-62.

${ }^{13}$ Ks. Leszczyński Bolesław (1871-1951) - kapłan diecezji pińskiej. Święcenia kapłańskie przyjął w 1894 roku. Był pierwszym proboszczem parafii w Kłopotach Stanisławach, erygowanej przez bpa Jerzego Matulewicza. Na proboszcza został mianowany dnia 16 grudnia 1922 roku i pracował w tej parafii do 1925 roku. W 1926 roku objął obowiązki administratora parafii św. Rocha w Mielniku, dekanat Drohiczyn. W 1930 roku został proboszczem w Siehniewiczach. W 1938 roku został mianowany rektorem kaplicy drewnianej w Walówce (poświęconej w 1934 roku), dekanat Nowogródek. Po 1945 roku pracował na terenie Białoruskiej Socjalistycznej Republice Radzieckiej - w parafii Niepokalanego Poczęcia NMP w Niehniewiczach, w tym samym dekanacie. Elenchus ecclesiarum et cleri dioecessis pinsceensis pro Anno Domini 1932, Pinsci 1932, s. 61; L. Mikhailik, Kościót katolicki na Grodzieńszczyźnie 1939-1956, Warszawa 2008, s. 229, 309; Z. Rostkowski, Zarys historii parafii pw. Matki Bożej Różańcowej w Kłopotach Stanisławach, Edycja podlaska 28/2005, http://niedziela.pl/artykul/43207/nd/Zarys-historii-parafii-pw-Matki-Bozej (dostęp: 20.11.2018). 
Kumor Bolesław, Ustrój i organizacja Kościoła polskiego w okresie niewoli narodowej 1772-1918, Kraków 1980.

Litak Stanisław, Kościół łaciński w Rzeczypospolitej około 1772 roku, Lublin 1996, s. 7879.

Mikhailik Larysa, Kościót katolicki na Grodzieńszczyźnie 1939-1956, Warszawa 2008.

Pleskaczewska Anna, Puryfikacja, w: Encyklopedia Katolicka, t. 16, Lublin 2012, kol. 630-631.

Rąkowski Grzegorz, Ilustrowany przewodnik po zabytkach kultury na Białorusi, Warszawa 1997.

Spis kościołów i duchowieństwa diecezji pińskiej w R. P. 1939, Pińsk 1939, s. 130.

Straszewicz Marzena, Korporat, w: Encyklopedia Katolicka, t. 9, Lublin 2002, kol. 900901.

Syczewski Tadeusz, Katafalk, w: Encyklopedia Katolicka, t. 8, Lublin 2000, kol. 976.

Szymański Józef, w: Encyklopedia muzyczna PWM, Sm-Ś. Część Biograficzna, red. E. Dziębowska, Kraków 2007, s. 298.

Zielińska Zofia, Józef Prozor, w: Polski Słownik Biograficzny, t. 28, Wrocław 1984-1985, s. $532-534$.

\section{Netografia}

Produkcja fortepianów $w$ przedwojennym Wrocławiu, http://arspolonica.ocross.net/produkcja-fortepianow-we-wroclawiu/ (dostęp: 20.11.2018).

Rostkowski Zbigniew, Zarys historii parafii pw. Matki Bożej Różańcowej w Kłopotach Stanisławicach, Edycja podlaska 28/2005, http://niedziela.pl/artykul/43207/nd/Zarys-historii-parafii-pw-Matki-Bozej (dostęp: 20.11.2018).

Rostowski Zbigniew, Historia parafii pw. św. Andrzeja Apostoła w Wyszkach, „Niedziela”, http://niedziela.pl/wydruk/28896/nd (dostęp: 20.11.2018).

\section{INWENTARZ RZYMSKOKATOLICKIEGO KOŚCIOLA PARAFIALNEGO W SIEHNIEWICZACH Z 14 MAJA 1930 ROKU}

\section{Streszczenie}

Inwentarz Siehniewickiego rz-kat. parafialnego kościoła sporzadzony przez ks. Izydora Niedroszlańskiego przy zdaniu niniejszego nowo mianowanemu proboszczowi ks. Henrykowi Kazimierowiczowi w myśl zarządzenia J. E. Ks. Biskupa Pińskiego z dnia 14 maja 1930 roku pod $\mathrm{Nr}$ 1096/30

Pierwotny, drewniany kościół parafialny pw. Opieki Najświętszej Maryi Panny w Siehniewiczach, w diecezji łucko-brzeskiej ufundowany został w połowie XVI wieku. Murowaną świątynię ufundowali dla tej parafii Józef i Maria Prozorowie w 1785 roku. Spalona w 1915 roku przez Rosjan, w 1922 roku została odbudowana staraniem ówczesnego proboszcza ks. Izydora Niedroszlańskiego i dzięki ofiarności parafian i dobrodziejów. W latach II Rzeczypospolitej parafia w Siehniewiczach znalazła się w granicach erygowanej w 1925 roku diecezji pińskiej. Decyzją pasterza tej diecezji. biskupa Zygmunta Łozińskiemu z 14 maja 1930 roku jej proboszcz ks. Izydor Niedroszlański przekazał ją swemu następcy w Siehniewiczach. W sporządzonym z tej okazji inwentarzu-protokole dowia- 
dujemy się o historii świątyni, jej odbudowach i remontach, wyposażeniu i konserwacji wystroju o świątyni, jej odbudowach, wyposażeniu i konserwacji wystroju. Opisane dobra materialne przynależne da parafii ukazują stan beneficjum kościelnego $\mathrm{w}$ tamtych czasach. Inwentarz zamieszcza opis zabudowań gospodarczych, aktualnego inwentarza kościelnego i biura i archiwum parafialnego.

Słowa kluczowe: historia Kościoła; historia diecezji pińskiej; parafia w Siehniewiczach; inwentarze kościołów parafialnych; beneficjum parafialne

\title{
ИНВЕНТАРЬ РИМСКО-КАТОЛИЧЕСКОГО ПРИХОДСКОГО КОСТЕЛА В СЕГНЕВИЧАХ ОТ 14 МАЯ 1930 Г.
}

\section{Содержание}

Первый деревянный приходской костел во имя Покровительства Пресвятой Девы Марии в Сегневичах Луцко-Брестской епархии был возведен в середине XVI века. В 1785 г. Иосиф и Мария Прозоровы пожертвовали средства на каменный храм для прихода. Этот храм был сожжен русскими в 1915 г., но был восстановлен в 1922 г. благодаря усилиям тогдашнего настоятеля о. Исидора Недорошлянского и пожертвованиям местных прихожан и благотворителей. Во времена II Речи Посполитой приход в Сегневичах оказался в составе новой Пинской епархии, созданной в 1925 г. По распоряжению пастыря этой епархии епископа Сигизмунда Лозинского от 14 мая 1930 г. настоятель о. Исидор Недорошлянский передал приход в Сегневичах своему преемнику. Из составленного по этому случаю инвентаря можно узнать об истории храма, его перестройке и ремонтах, оборудовании и консервации внутреннего убранства. Описанное материальное имущество, принадлежащее приходу, дает представление о состоянии бенефиций костела в то время. В инвентаре содержится описание хозяйственных строений, текущего костельного инвентаря, приходской канцелярии и архива.

Ключевые слова: история католической Церкви; история Пинской епархии; приход в Сегневичах; инвентари приходских костелов; приходские бенефиции

Перевод Лауры Михайлик

\author{
ИНВЕНТАР РЫМА-КАТАЛЦКАГА ПАРАФІЯЛЬНАГА КАСЦЁЛА Ў \\ СЕГНЕВІЧАХ 314 МАЯ 1930 Г.
}

\begin{abstract}
Змест
Начало формы Першы драўляны парафіяльны касцёл у імя Апекі Найсвяцейшай Марыі Панны ў Сегневичах Луцка-Брэсцкай дыяцэзіі быў узведзены ў сярэдзіне XVI стагоддзя. У 1785 г. Юзаф і Марыя Прозоровы ахвяравалі сродкі на му-
\end{abstract}


раваны храм для парафіi. Гэты храм быў спалены рускімі ў 1915 г., але адноўлены ў 1922 г. дзякуючы намаганням тагачаснага пробашча кс. Ісідара Недарашлянскага i ахвяраванням мясцовых вернікаў і дабрачынцаў. У часы II Рэчы Паспалітай парафія у Сегневичах апынулася ў складзе новай Пінскай дыяцэзіi, утворанай у 1925 г. Па распараджэнні пастыра гэтай дыяцэзіі біскупа Зыгмунта Лазінскага ад 14 мая 1930 г. пробашч а. Ісідар Недарашлянскі перадаў парафію ў Сегневичах свайму пераемніку. Са складзенага з гэтай нагоды інвентара можна даведацца пра гісторыю храма, яго перабудове і рамонтах, абсталяванні і кансервацыі ўнутранага строя. Апісаная матэрыяльная маёмасць, якая належыць парафіi, дае ўяўленне аб стане бенефіцыяў касцёла ў той час. У інвентары змяшчаецца апісанне гаспадарчых пабудоў, бягучага касцёльнага інвентару, парафіяльнай канцылярыі і архіва.

Ключавыя словы: гісторыя Касцёла; гісторыя Пінскай дыяцэзіі; парафія ў Сегневічах; інвентары парафіяльных касцёлаў; парафіяльныя бенефіцыі

Пераклад Лауры Михайлик

\title{
THE INVENTORY OF THE CATHOLIC CHURCH IN SIEHNIEWICE OF 14 MAY 1930
}

\begin{abstract}
Summary
The first wooden parish St. Mary of Assistance church in Siehniewice in the diocese of Łuck-Brześć has been founded in the middle of XVIth century. The church built of bricks have established in 1785 Józef and Maria Prozorowie. The church has been burned by the Russians in 1915 and 1922 reconstructed by the pastor father Izydor Niedroszlański und thanks to the support of the parishioners and benefactors. During the years of the Second Republic the parish of Siehniewice was placed in the new 1925 created diocese of Pińsk. The Bishop Zygmunt Łoziński gave on 14 May 1930 the administration of that parish to the successor of farther Izydor Niedroszlański. From the at that time completed inventory we are getting knowledge about the history of that parish and church, about the successively done constructions and reconstruction, about the equipment and decorations of that church. The in the inventory described material means of the parish are revealing the church preferment. The inventory is describing also the parish buildings, archives and office.
\end{abstract}

Key words: Church history; the history of the diocese of Pińsk; the parish of Siehniewice; the inventory of the parish churches; the church preferment 